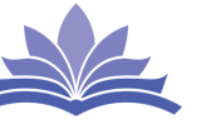

\title{
SHAKESPEAREAN LITERATURE CIRCLE: A TOOL TO DEVELOP LANGUAGE SKILLS FOR EFL/ESL LEARNERS
}

\author{
K.M.Wazed Kabir ${ }^{1}$, Mohammad Golam Mohiuddin ${ }^{2}$
}

\author{
Chairperson \& Associate Professor, Department of English, Green University of Bangladesh, Dhaka \\ Senior Lecturer, Department of English, Green University of Bangladesh, Dhaka \\ chairman.eng@green.edu.bd
}

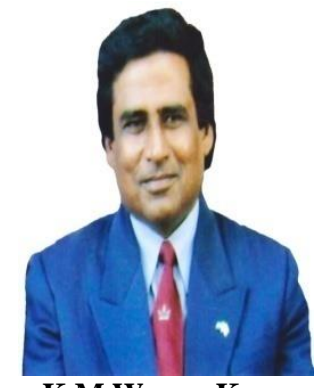

K.M.WAZED KABIR

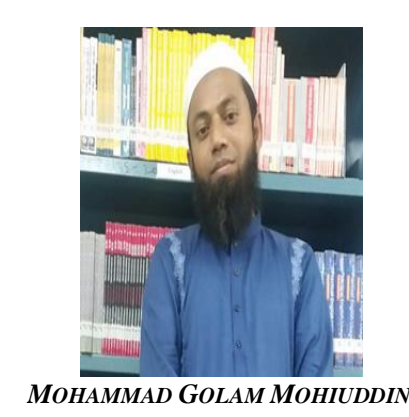

Keywords: Literature Circle, EFL/ESL, Tool, Elhess and Egbert, Language Skills

\begin{abstract}
A B S T R A C T
This paper sheds light on the ways how a literature circle helps improve English Language skills. A literature circle is a student centered practice session where each student gets directly involved in the work and the teacher acts as a passive actor in the back just to control the function. In this paper, the researchers adopt the literature circle model designed and practiced by Elhess and Egbert (2015). The study is conducted on 22 BRAC Nobodhara School teachers who have received in-service training offered by the BRAC Institute of Languages, BRAC University. All the teachers having Masters Graduation in various disciplines have mixed level English language proficiency. The course objective is to develop their language proficiency to a higher level so that they can use the target language both inside the classroom and even outside. In the paper, the researchers have adopted a qualitative approach and taken texts from A Midsummer Night's Dream, a comedy written by Shakespeare between 1590 and 1597. Five individual roles, namely Discussion Director, Literary Luminary, Illustrator, Summarizer, and Vocabulary Enricher are allotted to the members of the circle so that they can work smoothly and effectively. While discussing and helping each other in the circle, every member of the group will execute his/her assigned role and responsibility. These discussion, collaboration and scaffolding in the circle to help members create a conducive environment to accelerate language learning. The researchers, thus, believe that teaching language through Shakespearean literature circle will eventually increase learner participation in a safe environment, enhance responsibility and motivation, expand collaborative discussion, develop oral proficiency, increase scaffolding opportunities and reinforce writing skills. Still, further research is encouraged in the same area to unearth the underneath.
\end{abstract}

Citation: K.M.Wazed Kabir, Mohammad Golam Mohiuddin (2018). Shakespearean Literature Circle: A Tool To Develop Language Skills For Efl/Esl Learners. International Journal of Advanced Multidisciplinary Scientific Research (IJAMSR ) ISSN:2581-4281 Vol 1, Issue 3, May, 2018, \#Art.132, pp30-40

\section{Introduction}

The literature reflects life, represents the dictionary of life and uses language in contexts for which it is almost impossible to divorce literature, language and life from one another. Life and literature emerge together as true companions. According to Lorenzo (2014), 


\section{International Journal of Advanced Multidisciplinary Scientific Research (IJAMSR) ISSN:2581-4281}

Long before human civilization started in this world, stories are found among the constellations, beneath the depths of the oceans, and within the woodland realm. Long before language was invented, stories were told and engraved upon stone tablets and wall carvings. Long before humans began to know how to read and write with the words that our ancestors created, literature already existed. (Para 1)

A good piece of literature is replete with information, interactions, responses and messages which are the sources of language learning and teaching. Language learning becomes much effective when it encourages developing responses and reinforcing messages. The more varied the responses are, the richer the language learning will become. Literature, thus, does not keep us confined to mechanical responses, formulaic, and discrete language teaching and learning, rather it gives us a wide exposure to practice and learn the language. Hamdoun \& Hussain (2015) believe that Literature offers a wide range of language structures, which can enhance our understanding of the range of language usages. This understanding of language usages has a direct impact on the learners' ability to learn and use language not for mechanical responses, but for the expression and response of those thoughts and ideas which would have stifled in the brain in the absence of rich language resources. Literary work, in such a situation, becomes a vehicle for language learning.

Teaching and learning languages, in particular English, have been embracing various approaches, methods and techniques throughout the world and these ways of teaching and learning are being changed with the changes of time. Teaching English language through literature or literature circle has been getting popularity again throughout the whole world, though there was controversy regarding the use of literature in language class. A literature circle, an instructional approach and activity in which members meet to discuss and respond to a book they are all reading, help English language learners improve both reading comprehension and overall language performance. Daniels (2002) discusses these types of benefits of a literature circle

...literature circles have the potential to transform power relationships in the classroom, to make kids both more responsible for and more in control of their own education, to unleash lifelong readers, and to nurture a critical, personal stance toward ideas. (P. 31)

In a peer-led literature circle, each student gets much more exposure and feels less risk than in a whole-class discussion. There is more positive peer pressure to join in when the group is small and run cooperatively by students, not by the teacher. In this paper, the researchers have adopted a literature circle model (Daniels and Steineke, 2004) where five individual roles, namely Discussion Director, Literary Luminary, Illustrator, Summarizer, and Vocabulary Enricher will be assigned to members of the literature circle to allow the group to function productively. The researchers have selected texts from Shakespeare's comedy A Midsummer Night's Dream as a tool to develop English language skills of a group of adult learners in an EFL (English as a Foreign Language) /ESL (English as a Second Language) context. Whether English in Bangladesh is a foreign or a second language is still controversial. According to Hamid (2009, cited in Haque \& Mohiuddin, 2014), Whether English in Bangladesh is a foreign or a second language remains debatable. However, English is increasingly penetrating the society and becoming widely popular. With the rapid advancement of science and technology, trade and commerce, education and communication and with the development of 


\section{International Journal of Advanced Multidisciplinary Scientific Research (IJAMSR) ISSN:2581-4281}

globalization, the English language has made its domain even in a country Bangladesh where people have strong nationalistic and linguistic feelings for their nations and language. As it is observed by Haque and Mohiuddin (2014), "Even though English is a de jure foreign language in Bangladesh, it has turned to an aide facto second language here". (P. 106)

Whatever is the status of English in Bangladesh- EFL, or ESL does not matter; but the development of English language skills for the people of Bangladesh matters. To enhance English language skills, critical thinking and analytical ability of the learners, the researchers have used a literature circle for a group of mixed ability adult learners, that is, BRAC Nobodhara School Teachers who have been receiving in-service teacher training of a sixty hour long course. In the middle of the course, the teachers as researchers have selected a very interesting text from a Shakespearean comedy keeping in mind the age, interest and level of the learners with that of the text. Thus, the rationale of the paper is justified by providing the scope for adult learners to develop their comprehension skill, language skills, analytical ability, critical thinking based on the practice of a Shakespearean literature circle.

\section{Use of Literature Circle}

A literature circle integrates the best practices of collaborative learning and student-led learning. It guides students to a deeper understanding of what they read through structured discussion and extended written and artistic response. A literature circle is a form of literary engagement that encourages learners to read with a focus and then report on and discuss what they read, determining for themselves what is significant in their reading and why. It encompasses much more than similar approaches such as book clubs (Raphael, FlorioRuane, \& Geroge, 2001) or peer-led discussion groups (Fountas \& Pinnell, 2001) (Cited in Marshall, 2006). According to Schlick Noe (2004),

In literature circles, small groups of students gather together to discuss a piece of literature in depth. The discussion is guided by students' response to what they have read. You may hear talk about events and characters in the book, the author's craft, or personal experiences related to the story. Literature circles provide a way for students to engage in critical thinking and reflection as they read, discuss, and respond to books. Collaboration is at the heart of this approach. Students reshape and add onto their understanding as they construct meaning with other readers. (Para 3)

The following table helps us understand well what literature circles are and what they are not.

\section{Table 1: Literature Circles- What and what} not

\begin{tabular}{|l|l|}
\hline Literature Circles are. . & Literature Circles are not... \\
\hline $\begin{array}{l}\text { Reader response } \\
\text { centered }\end{array}$ & Teacher and text centered \\
\hline $\begin{array}{l}\text { Part of a balanced } \\
\text { literacy program }\end{array}$ & The entire reading curriculum \\
\hline $\begin{array}{l}\text { Groups formed by } \\
\text { book choice }\end{array}$ & $\begin{array}{l}\text { Teacher-assigned groups } \\
\text { formed solely by ability }\end{array}$ \\
\hline $\begin{array}{l}\text { Structured for student } \\
\text { independence, } \\
\text { responsibility, and } \\
\text { ownership }\end{array}$ & $\begin{array}{l}\text { Unstructured, uncontrolled "talk } \\
\text { time" without accountability }\end{array}$ \\
\hline $\begin{array}{l}\text { Guided primarily by } \\
\text { student insights and } \\
\text { questions }\end{array}$ & $\begin{array}{l}\text { Guided primarily by teacher- or } \\
\text { curriculum-based questions }\end{array}$ \\
\hline $\begin{array}{l}\text { Intended as a context } \\
\text { in which to apply } \\
\text { reading and writing } \\
\text { skills }\end{array}$ & Intended as a place to do skills \\
\hline $\begin{array}{l}\text { Flexible and fluid; } \\
\text { never look the same } \\
\text { twice }\end{array}$ & Tied to a prescriptive "recipe" \\
\hline
\end{tabular}

Schlick Noe, K.L. \& Johnson, N.J. (1999) 


\section{International Journal of \\ - The cultural model \\ - The language model \\ - The personal growth model} Advanced Multidisciplinary Scientific Research (IJAMSR) ISSN:2581-4281

According to Daniels' (2002) definition,

"Literature circles are small, temporary discussion groups who have chosen to read the same story, poem, article, or book...[E]ach member prepares to take specific responsibilities in the upcoming discussion, and everyone comes to the group with the notes needed to help perform that job". (P. 13)

The practice of using literature, poetry and literature circles to develop language skills is widely identified throughout the world. Chen (2014) in his paper presents evidence that literature for children can be effectively used to acquire English as a foreign language in students of all ages. Students get benefit from being challenged with language input that is slightly beyond their independent level of comprehension. This comprehensible input can be provided by listening to the reading or the telling of a story. In his paper, he argues for the use of English literature of practical applications of language acquisition and learning principles in five categories of activities - story selection, listening, shared reading, independent reading, and drama.

Violetta-Irene (2015) argues that using literature in a language classroom makes the class interactive which can obviously improve communicative competence of the learners and keep a lasting impact on their mind. Such a class can enhance the critical thinking abilities of the learners and at the same time maintain a learner centered environment. It cultivates the critical abilities of the students and encompasses every human dilemma and conflict. The three main reasons for the teaching of literature have been consistently advanced. Each embraces a particular set of learning objectives for the student. These are:
Hanauer (2001) analyzed the role of the poet reading task for foreign language learning. The study involved twenty female university students, registered in a teacher training course in Israel. None of the participants had degrees in English or Hebrew literature. The results of the study were clearly positive, categorizing the task of poetry reading as a useful technique in the foreign language classroom when working with advanced learners. As the author states, poetry-reading can facilitate the development of both linguistic and cultural knowledge of the target language.

Butler (2006) provides an example of an attempt to incorporate literature into language classes in a South African context. The English course he describes, implemented in the context of the University of North West, included four components: Introduction to English Studies, Introduction to Textual Analysis, Introduction to Literary Genres and Grammar Awareness. Based on the integrated approach between language and literature elements, the course resulted to be evaluated in a highly positive way (with $86 \%$ of students in favor of the integrated approach).

Minkoff (2006) tries to justify the role of an elective literature and language course for students majoring in business management. Using Barnes's (1991) book Talking it Over to illustrate his approach, the author describes the structure of the lessons and offers an overall evaluation of the experiment. Surprisingly, most of the students evaluated the course as a great success in spite of the fact that business students might initially seem to have had little need to acquire literature background knowledge. 


\section{International Journal of Advanced Multidisciplinary Scientific Research (IJAMSR) ISSN:2581-4281}

The study conducted by Lin (2006) is set in a secondary school in Singapore, where English is the second language for most of the students and language and literature are usually taught as separate subjects. The author claims for the pedagogical need to embed literature into a larger framework of language classes. Anwar and Rana (2010) provide the data of an empirical investigation conducted in the context of Pakistan with 280 university students enrolled in different English language and Literature courses. After having analyzed the students' responses to the questionnaires that had been previously administered, the authors reported that most of the students considered literature as a helpful component in language studies and as an effective source to be used in the language class.

Yeasmin and et al (2011) emphasized the effectiveness of using literature in EFL classes through a project titled “Readers' Development Program”. Their paper reviews the arguments for using literature in the language classroom and shows that literary texts provide a wide scope to explore multi-dimensional use of the language. Literary pieces, especially stories are more attractive and fascinating than other teaching materials and allow group discussions and individual explorations. They offer real language use, which creates a feeling for the language in the students. Activities like role plays, group discussions and presentations reduced the level of anxiety in the students and they got involved in the language with enthusiasm and interest. It is suggested that selecting the texts properly and designing a different set of activities according to the needs of the learners can facilitate language teaching and learning.
Chen (2014) focuses on the importance of literature for children to be an effective tool to develop language skills for the learners of all ages and Hanauer (2001) analyzes the role of the poetry reading task for foreign language learning whereas this paper focuses on the text of a Shakespearean comedy to develop English language skills of adult learners. Again, Butler's (2006) efforts concentrate on the incorporation of literature into language classes in a South African context and Minkoff (2006) tries to justify the role of an elective literature and language course for students majoring in business management. But the present paper is unique and interesting in its selection of the text from a comedy of Shakespeare for the adult learners in their in-service training program. Both Anwar \& Rana (2010) and Yeasmin and et al (2011) conducted their studies with university students; instead the present paper has attempted to work with the participants who have Masters Graduation in various disciplines and teaching experiences. Hence, this paper is distinctive from the others for its uniqueness.

\section{Methodology}

The research was conducted in a very natural classroom setting. The researchers adopted qualitative approach to carry out the research. They observed participant's interaction, practice and progress and had a group discussion with them after their work. The study was conducted on 22 participants who have master degrees on various disciplines with limited English language proficiency. Among the participants, twenty were females and the rest two were males. All of them are teachers at BRAC Nobodhara School and receiving inservice training on English language proficiency. They were from 28 to 40 age range. Some of them have long teaching experiences whereas some are new. The 


\section{International Journal of Advanced Multidisciplinary Scientific Research (IJAMSR) ISSN:2581-4281}

researchers formed four groups of five members (in each) who were assigned with the roles of Discussion Director, Literary Luminary, Illustrator, Summarizer, and Vocabulary Enricher. The rest two members were helping and working with two particular groups. As instruments, the researchers provided each group particularly the Illustrator with a poster paper and a pencil to draw the picture of the text. As it has been mentioned, the researchers have adopted literature circle model suggested and practised by Daniels and Steineke (2004). The Discussion Director's task was to develop at least five questions about the text and then share these questions with the group. The Literary Luminary pinpoints important parts of the text for the group in order to stimulate thinking and elicit some interesting facts about the text. The Illustrator's job is to draw pictures related to the reading and share the drawings with the group; the group members then speculate on the meaning of the pictures and connect them to their own ideas about the text. The Summarizer's role is to recall what happened in the reading and prepare a summary for the group, and the Vocabulary Enricher helps the group find and discuss new or difficult words (Daniels and Steineke 2004). To accomplish the research, the researchers selected texts from page 2 to 3, Scene-2, Act -2 of Shakespeare's comedy A Midsummer Night's Dream. The researchers have intentionally selected the texts keeping in mind the level and interest of the learners. As the participants are adult, adaptable and interested in romantic reading, the texts have been chosen in line with their attention. Also, the researchers deliberately selected the two versions of the same text a. original text and b. modern text; and the participants were asked to work with the modern text so that they can comprehend and work on the text. Both the texts have shown here:

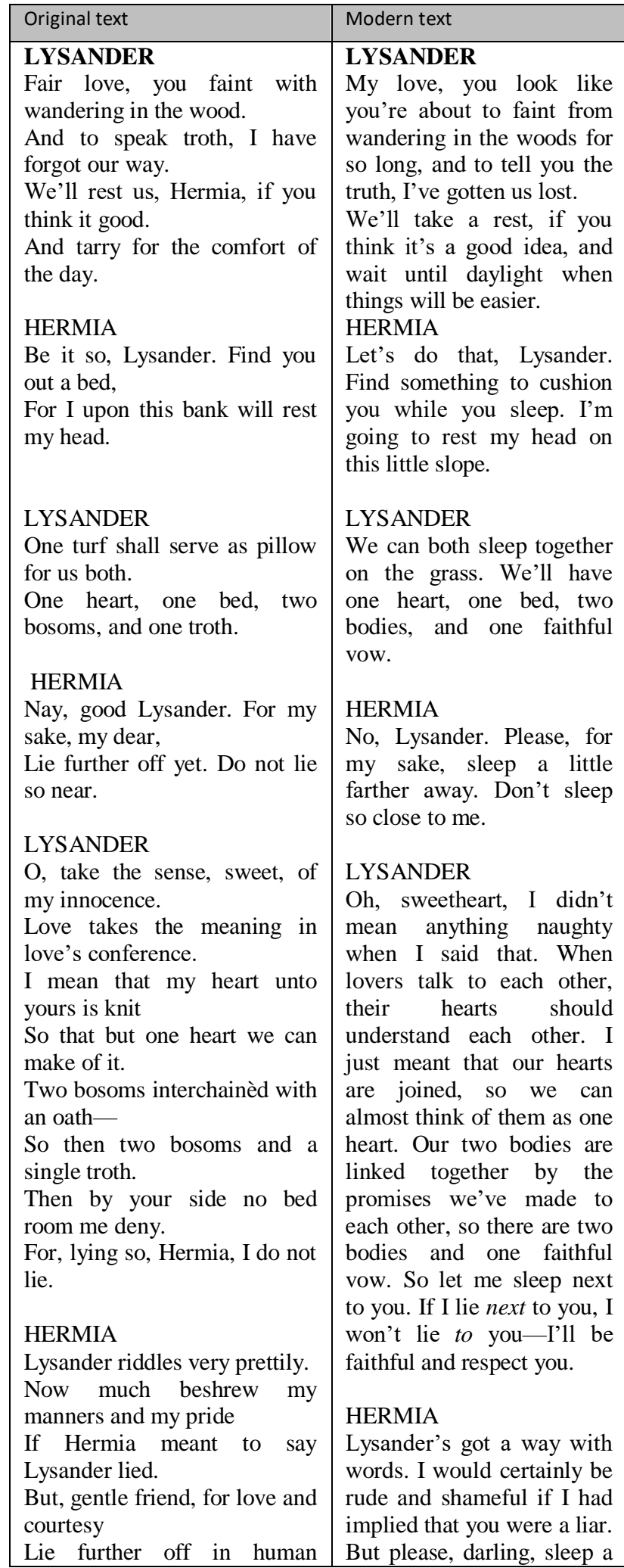


https://doi.org/10.31426/ijamsr.2018.1.3.132

I J A M S R

\section{International Journal of Advanced Multidisciplinary Scientific Research (IJAMSR) ISSN:2581-4281}

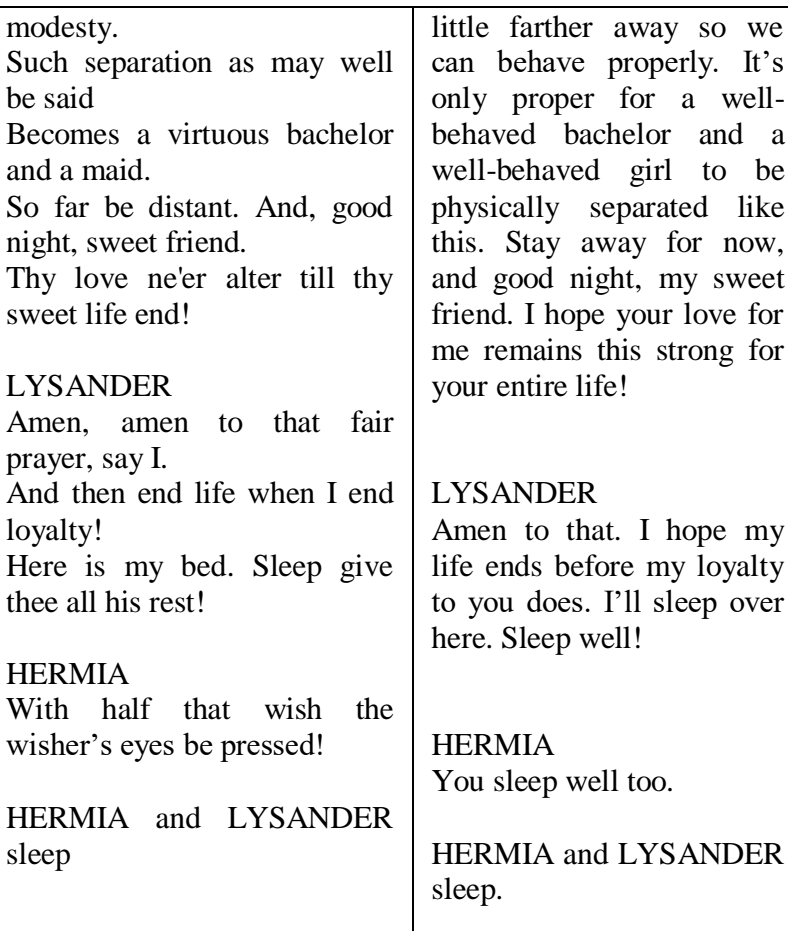

Source: Spark Notes, 2017

\section{Findings}

As it has been observed from the interaction and participation of the learners, using literature circles as an instructional approach in the classroom has the potential to create a positive and interactive environment for the development of the target language. From the observation, it was found that the Discussion Director scanned the text very enthusiastically to formulate five questions for the other members of the group. As soon as he threw the formulated questions to the group, the members replied very quickly and correctly. The role of the Literary Luminary was to identify vital parts of the text for the group to inspire thinking and bring out some interesting facts about the text. To make it happen, the Literary Luminary read the text very minutely in collaboration with other members. He brought in light how Lysander and Hermia argued showing love and respect to each other regarding their sleeping together on the grass. The Illustrator drew the image of the text with full interest and enthusiasm. The following are the samples of images drawn by the Illustrators of Group A and $\mathrm{B}$; as it was observed, these images added further interest in the mind and heart of the other members who could realize the text easily and interestingly and connect the picture with their understanding of the text.

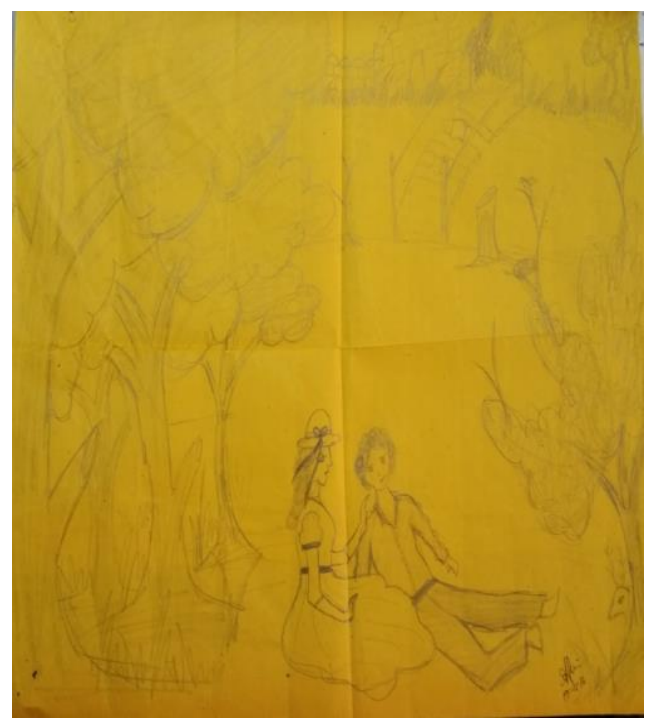

Figure-01: The picture of the selected text drawn by the Illustrator of Group -A

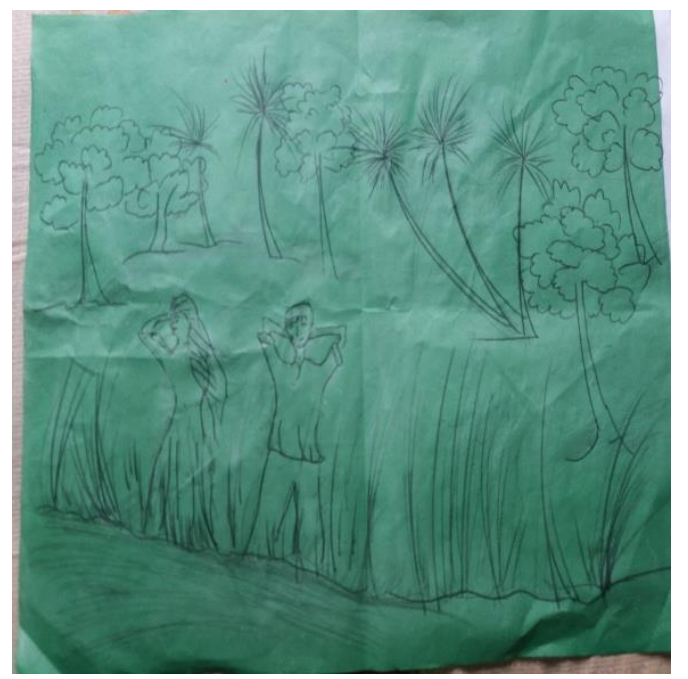

Figure-02: The picture of the selected text drawn by the Illustrator of Group -B 
https://doi.org/10.31426/ijamsr.2018.1.3.132

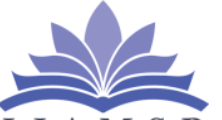

I J A M S R

\section{International Journal of} Advanced Multidisciplinary Scientific Research (IJAMSR) ISSN:2581-4281

The Summarizers abridged the text based on their reading and shared this before the group members who could recap the story. The following are the summary samples written by the summarizers of Group A and C.

\section{Summary of Group-A}

It's a conversation between a couple Lysander and Hermia. First of all Lysander proposed the Hermia can we take rest? and also great idea. Hermia agree with himbut she think Lysander need something diffrent. But, no Lysander needsaid only sleep at night together. Hermia very angree with Lysander and she telling to him sleep a little farther away. That time Lysander brief what is love who he mows. He also said our two bodies linked together and promisses we've to made each other. Hermia replied to him, please sleep little farther arvay and well-behaved like a bachelor. And Lysander said Amen and they sleep well.

\section{Summary of Group-C}

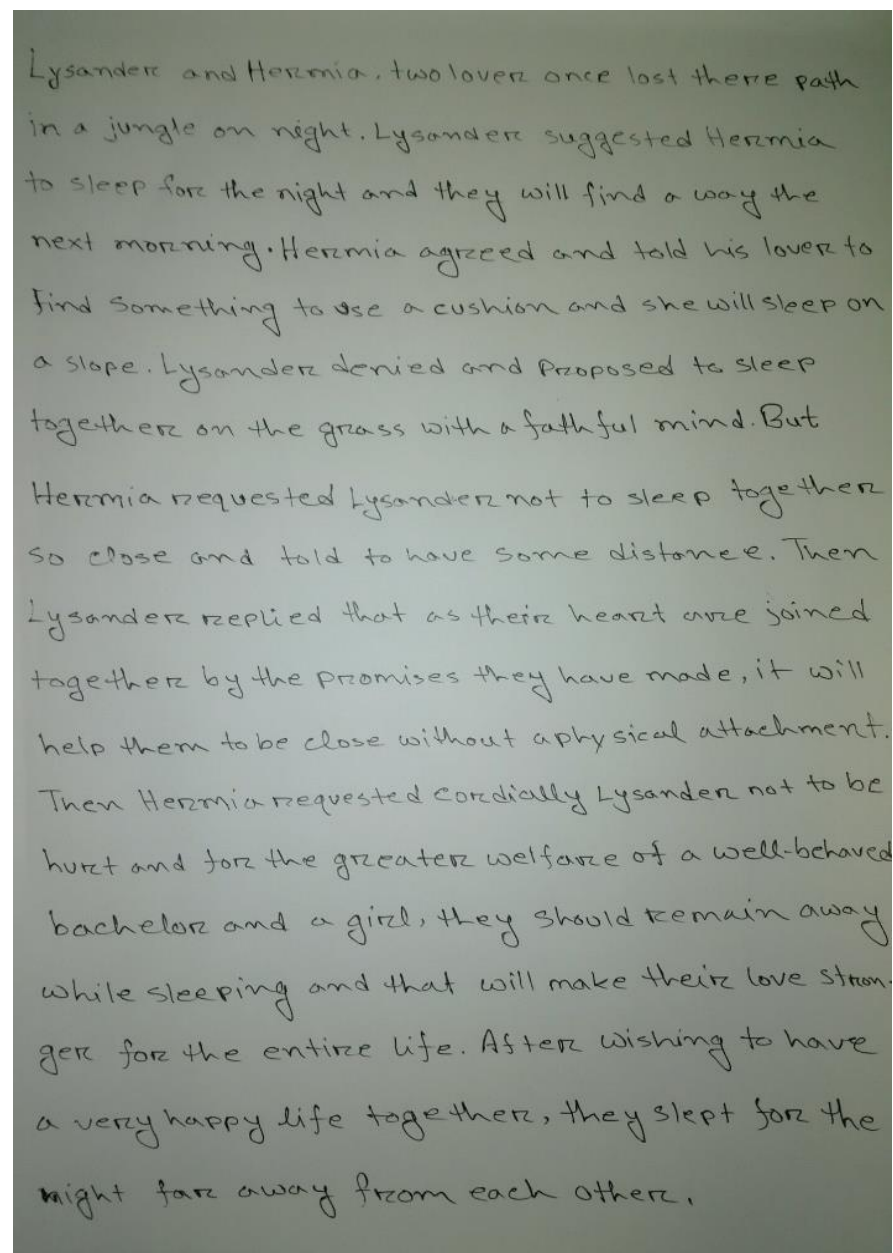

Figure-03: The samples of the summary writing by of Group A and C

The Vocabulary Enricher identified the new and difficult words and discussed them with examples. It was observed that each member of the group was working and enjoying his/her own role quite well. From the group discussion, the researchers came across interesting expression from the participants. All the participants have one expression in common that is they were very much excited with the text type and its story as because it went on according to their age and interest. Most of 


\section{International Journal of Advanced Multidisciplinary Scientific Research (IJAMSR) ISSN:2581-4281}

the members believe that the practice provided them an opportunity to enhance all the language skills. They claimed that they read, wrote, discussed and shared their understanding of the same text in group. They further argued it was the safest zone for them to work among themselves, sometimes with help of the teacher. The members also mentioned that each member was active and responsible as everyone was assigned with a certain task which was interrelated with that of the other. Also, they debate that while doing a specific task individually in the group, they supported each other sometimes. Thus, the discussion, the image drawn by the Illustrator, and the summary written by Summarizer including the all the assigned activities of the members showed how interesting and interactive the circle was.

\section{Discussion and Recommendation}

English language teachers, practitioners and linguists are paying diverse attention and offering different tools to develop language skills for EFL/ESL learners. As a part of these efforts, the researchers adopted literature circles based on the text of Shakespeare's A Midsummer Night's Dream and found very interesting, informative, and inspiring results which will be mile stones for other researchers and practitioners. As each student in literature circle is assigned with a specific task, this make him/her feel a sense of ownership and responsibility. The Discussion Director's enthusiasm in scanning the text to formulate five questions gave him/her a ground to improve his/her comprehension skills. According to Daniels and Steineke (2004), literature circles support strategies such as visualizing, connecting, questioning, inferring, and analyzing that are vital to solid comprehension and lively conversation. The Discussion Directors and all the participants in this paper were adult and the selected text was regarding the eloping of Lysander and Hermia to a forest and arguing with each other on the question sleeping together. Thus, the text went according to their level of interest resulted in the motivation and engrossment of reading, scanning and working on the text. Here, the researchers argue that in selecting text for literature circle, the teacher should consider the level of language proficiency and the age of the learners so that learners can sustain their enthusiasm and interest. Here, the researchers agree with Chen (2014) who also proposed story or text selection at the top out of five categories of activities to develop language skills through English literature. The Literary Luminary's pinpointing important parts of the text and discussing these with the members of the group to stimulate thinking and to elicit interesting facts were much more meaningful in creating opportunities to practice oral skills which ultimately helped them develop their oral proficiency. As Nagy \& Townsend (2012) comments, working in literature groups provides students with opportunities for social interaction and communication about issues important to them. The Illustrators turned the words of the text into pictures, shared and shaped their comprehension and opinions on papers for which they needed to read the text well, analyze the characters and understand the environment. The researchers do believe that it is a platform for the EFL/ESL learners to develop their not only comprehension skills but also analytical ability, critical thinking by participating in literature circle as well as working as illustrators. Thus, Violetta-Irene's (2015) strong stand to use literature in a language classroom in enhancing the critical thinking abilities of the learners and maintaining a learner centered environment matched with the belief of the researchers here. Webb et al. (1998) also believe that teachers can assign engaging and challenging group activities that stimulate students' critical thinking, such as choosing a different ending to a 


\section{International Journal of Advanced Multidisciplinary Scientific Research (IJAMSR) ISSN:2581-4281}

short story, writing a short critique, or addressing writing prompts that reflect knowledge of what they have read. Again, the summary of the text helped the members of the group to recollect what happened. In classroom practice, a teacher at the end of the session either recaps the whole class or makes students recall what happened whereas in literature circles students themselves do the same practice among themselves with the help of the summarizer. Because, the summary of the text helps learners to recall the whole event and also, ensures the development of the writing skills of the learners. So far as the role of the Vocabulary Enricher is concerned, the researchers strongly believes that he (the Vocabulary Enricher) has a great contribution in developing English language by providing definition and examples of new and difficult words. Furthermore, the learners' feelings to work in literature circle and among themselves to be the safest zone send us a great message. This message has been reinforced and strengthened with the belief of Yeasmin and et al (2011) who think that discussions and presentations among students reduce the level of anxiety in the students and they get involved into the language with enthusiasm and interest. This ensures that collaborative learning or scaffolding helps students realize that their reading challenges are solvable, and also increases their interest and involvement in the given activity. As Elhess and Egbert (2015) comment:

Through interactive discussions and collaborative tasks, learners complete conversational and written activities that expose them to diverse responses and perspectives. These experiences not only help improve their basic language and literacy skills, but may also help to develop high-order thinking skills that are vital for helping learners to grow as independent and autonomous readers. (P.21)

\section{Conclusion}

Collaboration and peer supports in literature circles in the context of classroom practices help learners to sustain their motivation and involvement that result in the development of their communication skills and other life skills in a very conducive environment. As Elhess and Egbert (2015) state, "using literature circles as an instructional approach in the classroom has the potential to create a positive and interactive environment" (p.21). Through interactive discussions and collaboration in the circles, learners practise oral and written activities that expose them to diverse responses and perspectives. It is evident from this paper that the use of literature circles in language classroom ensures learners' motivation, engagement, and execution of the assigned responsibility. Since the assigned roles in literature circles require students to draw the events, create questions, and summarize the text, learners are called upon to use a variety of strengths and skills to prepare for the discussion which develop oral proficiency, increase scaffolding opportunities, reinforce writing skills and improve analytical ability and critical thinking. Also, the assigned responsibility makes learners feel and develop a sense of possession and accountability. Thus, a Shakespearean literary text, which goes according to the level of the learners and is used in the literature circles, is a proven kit in the development of the learners' language and life skills. 
https://doi.org/10.31426/ijamsr.2018.1.3.132

I J A M S R

International Journal of Advanced Multidisciplinary Scientific Research (IJAMSR) ISSN:2581-4281

References

1. Anwar, B. R., \& Rana, A.K. (2010). Perceptive Study "Teaching English Literature through English Language". Saarbrucken: Lambert Academic Publishing.

2. Barnes, J. (1991). Talking It Over. London: Picador.

3. Butler, I. (2006). A brighter future? Integrating and for -year. In A. Paran (ed.), Literature in language teaching and learning (pp.11-25). Virginia: TESOL.

4. Chen, M.L. (2014). Teaching English as a Foreign Language through Literature. Retrieved from www.academypublication.com/issues/past/tpls/vol04/ 02/02.pdf.

5. Daniels, H. (2002). Literature Circles. Teacher Vision. Retrieved from https://www.teachervision.com/groupwork/teaching-methods/48704.html

6. Daniels, H. \& Steineke, N. (2004). Mini-lessons for literature circles. Portsmouth, NH: Heinemann.

7. Elhess, M. and Egbert, J. (2015). Literature Circles as Support for Language Development.

8. English Teaching Forum (13-21). Retrieved from https://americanenglish.state.gov/files/ae/resource fi les/03_etf 533 3_elhess_egbert.pdf.

9. Hamdoun, Q.H. \& Hussain, S.S. (2015). Teaching Language through Literature: A diagnostic study on the teaching of English as a Foreign Language. Retrieved from http://repository.ksu.edu.sa/jspui/bitstream/1234567 89/4906/1/Teaching\%20Language\%20through\%20L iterature\%20A\%20diagnostic\%20study\%20on\%20th e\%20teaching\%20of\%20English\%20as\%20a\%20Fo reign\%20Language.pdf.

10. Hanauer, D. (2001). The task of poetry reading and second language learning. Applied Linguistics, 295323.

11. Haque, M.S. \& Mohiuddin, M.G. (2014). Armed forces register: A survey of the high-frequency English lexis in Bangladesh Army. Panini. 6 (20112012).

12. Lin, B. (2006). Genre-based teaching and Vygotskian principles in EFL: The case of a university writing course. Asian EFL Journal, 8 (3).

13. Lorenzo, A. (2014). Literature Is Powerful. Literature Defines Humanity. Retrieved from http://thoughtcatalog.com/angelolorenzo/2014/03/literature-is-powerful-literaturedefines-humanity/.

14. Marshall, J.C. (2006). The Effects of Participation in Literature Circles on Reading

Comprehension. Retrieved from

http://scholarlyrepository.miami.edu/oa_dissertations/50/.

15. Minkoff, P. (2006). Talking it over in class. In A. Paran (ed.), Literature in language teaching and learning. Virginia: TESOL.

16. Nagy, W. \& Townsend, D. (2012). Words as tools: Learning academic vocabulary as language acquisition. Reading Research Quarterly, 47 (1): 91-108.
17. Notes, S. (2017). A Midsummer Night's Dream Retrieve from

http://nfs.sparknotes.com/msnd/page 54.html

18. Schlick Noe, K.L. \& Johnson, N.J. (1999). Getting Started with Literature Circles. Norwood, MA: Christopher-Gordon Publishers, Inc. Retrieved from http://www.litcircles.org/Overview/overview.html.

19. Schlick Noe, K. L. (2004). Literature Circles Resource Center. Retrieved frhttp://www.litcircles.org/Overview/overview.html\# what.

20. Violetta-Irene, $K$. (2015).The Use of Literature in the Language Classroom: Methods and Aims, International Journal of Information and Education Technology. Vol. 5(1). Retrieved from http://www.ijiet.org/papers/479-H10011.pdf.

21. Webb, N. M., Nemer, K. M., Chizhik, A. W. \& Sugrue, B. (1998). Equity issues in collaborative group assessment: Group composition and performance. American Educational Research Journal, 35 (4): 607-651.

22. Yeasmin, N., Azad, M.A.K. \& Ferdoush, J.(2011).Teaching Language through Literature: Designing Appropriate, ASA University Review, Vol. 5 (2). Retrieved from http://www.asaub.edu.bd/data/asaubreview/v5n2sl21 .$p d f$. 